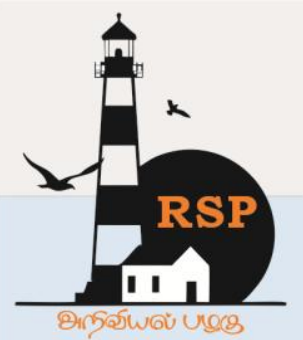

INTERNATIONAL RESEARCH JOURNAL ON ADVANCED SCIENCE HUB

RSP SCIENCE HUB

(The Hub of Research Ideas)

Available online at www.rspsciencehub.com

Special Issue of First International Conference on Information Technology, Computing \& Applications (ICITCA 2021)

\title{
Development of Battery Pack for Electric kart
}

Ravindra Parab ${ }^{1}$, Sudhanshu Chaturvedi ${ }^{2}$, Anuj Chouhan ${ }^{3}$, Chinmay Wayal ${ }^{4}$, Siddharth Chandnani ${ }^{5}$

${ }^{1}$ Department of Electrical and Electronics Engineering, Malwa Institute of Technology, Indore. India.

2,3,4,5 School of Mechatronics Engineering, Symbiosis University of Applied Sciences, Indore, India.

Ravindra.parab.80@gmail.com ${ }^{l}$

\begin{abstract}
This paper deals with development and application of Battery Pack for an Electric Kart. A Battery Pack is an integral part of an Electric Kart. This paper highlights the challenges in the development of a battery pack and its application. Since there is a gradual shift towards the electric vehicle from the traditional combustion engine vehicles, there is a requirement of research and improvement in the field of batteries used in an Electric Kart. This paper purely focuses on the development of a battery pack with nominal range and power output with phenomenal charging rate; keeping in mind the economic perspective of the power pack.
\end{abstract}

Keywords: Memory Effect, Electric Kart, Power Pack, Battery life cycle

\section{Introduction}

In today's world, application of Battery Pack is ever increasing as per the increase in the requirement of the Electric Vehicles. They play a vital role in providing constant supply of energy in an Electric Vehicle and lithium-ion batteries are widely used due to their supremacy over the other types of batteries. The nickel-based Li-ion battery, has a nominal voltage of $4 \mathrm{~V}$, energy density of $200 \mathrm{Wh} / \mathrm{l}$, specific energy of $120 \mathrm{Wh} / \mathrm{kg}$, and a specific power of $260 \mathrm{~W} / \mathrm{kg}$, which is approximately three times that of Ni-MH. Secondly its high-energy efficiency due its simple battery reaction. Then it's ease of controllability of electrical management. Another advantage is it's rechargeability property. Then it also has high energy density no memory effect (is an effect observed in nickel-cadmium and nickel-metalhydride rechargeable batteries that causes them to hold less charge). It has a relatively low selfdischarge. [1-4].

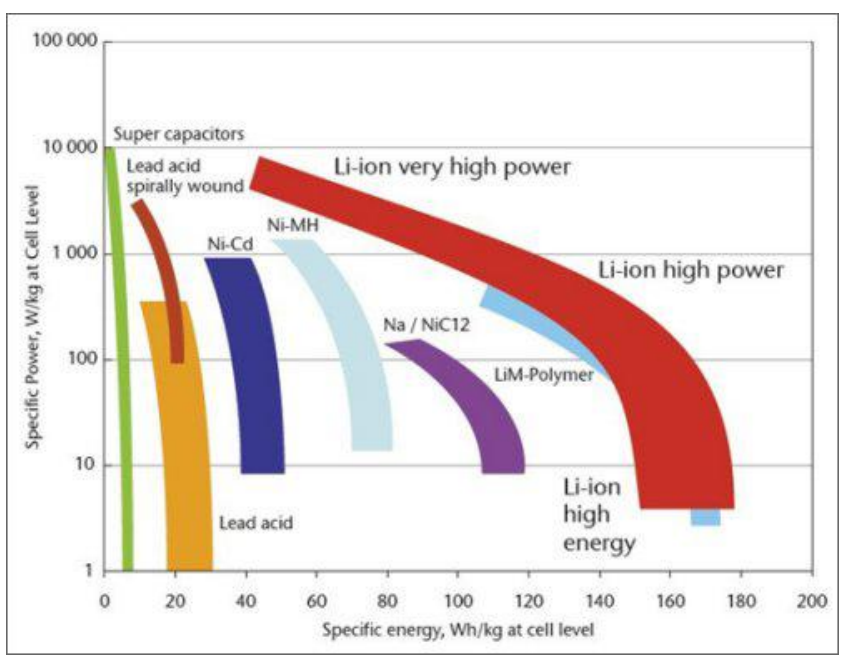

Fig. 1. Specific Energy comparison of various types of batteries [1]

They can however have safety hazards since they contain flammable electrolytes also, the excessive charging and discharging process can generate active chemical reaction and can even cause explosion in battery. It needs protection circuit to keep voltage and current within safety limits. It is very expensive to manufacture, and around $40 \%$ higher in cost than the nickel-cadmium batteries. 
The performance is greatly affected by high temperatures i.e., above certain temperatures performance of the battery pack is affected greatly. This paper focuses on the development of compact battery pack with high performance. This paper focused on the design and application of compact battery pack with required structural safety also with high cooling performance Efficient cooling system for the Battery Pack was also accomplished through computational fluid dynamic (CFD) analysis, to have minimized pressure drop within the pack under normal charging and discharging conditions and constant temperature distribution. Thus, introducing Li-ion Battery pack for widened spectrum of application In Electric Vehicles, Electric Karts and others. [5-10].Also, the weight of an Electric vehicle is mainly affected by the weight of the battery installed in it, thus we focused on developing a battery pack to manage the weight requirement in an $\mathrm{EV}$.

\section{Objective}

To develop a Battery Pack for Electric Vehicles under $6 \mathrm{KW}$ Power range, for implementation in Electric karts which would be efficient enough for the use in EVs, rechargeable with various methods like Regenerative Braking and would be safe enough without any harmful hazards or dangers. To design a battery pack in such a way that it is compact and with desired structural and integral safety, high performance.

\section{Requirement Calculations}

The proposed battery pack is to be installed in an actual Electric kart thus there are certain requirements that the battery pack must match. Apart from providing motion to the vehicle the battery pack has to provide power to other electrical components of the vehicle, requirements will then determine the battery pack.[11-15].

\section{Peak power required:}

$\mathrm{v}=70 \mathrm{~km} / \mathrm{h}=19.44 \mathrm{~m} / \mathrm{sw}=\mathrm{v} / \mathrm{r}=19.44 / 0.14=$

$138.85 \mathrm{rad} / \mathrm{s} \tau_{\mathrm{p}}=\mathrm{m}^{*} \mathrm{~g} * \mathrm{r} *$ slope $\% \tau_{\mathrm{p}}=$

$195 * 9.81 * 0.14 * 0.1 \tau_{\mathrm{p}}=26.78 \mathrm{NmP}_{\mathrm{p}}=\tau_{\mathrm{p}} *{ }_{\mathrm{w}} \mathrm{P}_{\mathrm{p}}=$ $26.78 * 138.85 \mathrm{P}_{\mathrm{p}}=3718.41 \mathrm{~W}$

\section{Continuous Speed:}

$\mathrm{RPM}=\mathrm{v}_{\text {average }} * 60 * 1 / 2 \Pi \mathrm{r}$

$\mathrm{RPM}=50 * 1000 / 3600 * 60 * 1 /(2 \Pi * 0.14)$

$\mathrm{RPM}=947$

\section{Continuous Torque:}

$\mathrm{m}=195 \mathrm{~kg}$

$\rho=1.225 \mathrm{~kg} / \mathrm{m}^{3}$

$\mathrm{Cd}=0.9$ $\mu=0.013$

$\mathrm{v}=50 \mathrm{~km} / \mathrm{h}=13.89 \mathrm{~m} / \mathrm{s}$

$\mathrm{A}=0.4293 \mathrm{~m}^{2}$

$\mathrm{g}=9.81 \mathrm{~m} / \mathrm{s}^{2}$

$\mathrm{r}=0.14 \mathrm{~m}$

Drag Force:

$\mathrm{F}_{\mathrm{d}}=0.5 * \rho * \mathrm{Cd} * \mathrm{~A} * \mathrm{v}^{2} \mathrm{~F}_{\mathrm{d}}=$

$0.5 * 1.225 * 0.9 * 0.4293 * 13.89 * 13.89$

$\mathrm{F}_{\mathrm{d}}=45.65 \mathrm{~N}$

\section{Rolling Resistance:}

$\mathrm{F}_{\mathrm{r}}=\mathrm{m}^{*} \mathrm{~g} * \mu$

$\mathrm{F}_{\mathrm{r}}=195 * 9.81 * 0.013$

$\mathrm{F}_{\mathrm{r}}=24.86 \mathrm{~N}$

Total Force \& Torque:

$\mathrm{F}_{\mathrm{t}}=\mathrm{F}_{\mathrm{d}}+\mathrm{F}_{\mathrm{r}}$

$\mathrm{F}_{\mathrm{t}}=70.51 \mathrm{~N}$

$\tau=\mathrm{F}_{\mathrm{t}} * \mathrm{r}$

$\tau=9.87 \mathrm{Nm}$

\section{Maximum Speed:}

$\mathrm{v}_{\mathrm{m}}=\left(\Pi * \mathrm{D}^{*} \mathrm{~N}\right) / 60$

$\mathrm{v}_{\mathrm{m}}=(\Pi * 0.28 * 1326) / 60$

$\mathrm{v}_{\mathrm{m}}=19.44 \mathrm{~m} / \mathrm{s}=70 \mathrm{~km} / \mathrm{hr}$

Torque at wheel $\left(\tau_{\mathrm{w}}\right)=\tau_{\mathrm{m}} *$ transmission

efficiency*total reduction $\tau_{\mathrm{w}}=9.6 * 0.98 * 25 / 11=$

$21.38 \mathrm{Nm}$

\section{Acceleration:}

$\mathrm{a}=\tau_{\mathrm{w}} / \mathrm{m} * \mathrm{r}=21.38 /(190 * 0.14)$

$\mathrm{a}=0.8 \mathrm{~m} / \mathrm{s}^{2}$

\section{Total Resistance:}

$\mathrm{m}=195 \mathrm{~kg}$

$\rho=1.225 \mathrm{~kg} / \mathrm{m}^{3}$

$\mathrm{Cd}=0.9$

$\mathrm{a}=0.8 \mathrm{~m} / \mathrm{s}^{2}$

$\mu=0.013$

$\mathrm{v}=60 \mathrm{~km} / \mathrm{h}=16.67 \mathrm{~m} / \mathrm{s}$

$\mathrm{A}=0.4293 \mathrm{~m}^{2}$

$\mathrm{g}=9.81 \mathrm{~m} / \mathrm{s}^{2}$

$\mathrm{r}=0.14 \mathrm{~m}$

$\mathrm{N}=1111.89 \mathrm{RPM}$

The Power required for Electric Kart is given by:

$\mathrm{P}_{\mathrm{t}}=\mathrm{P}_{\mathrm{d}}+\mathrm{P}_{\mathrm{r}}+\mathrm{P}_{\mathrm{i}}$

$\mathrm{P}_{\mathrm{t}}=$ Total Power

$\mathrm{P}_{\mathrm{d}}=$ Power due to Aerodynamic Drag

$\mathrm{P}_{\mathrm{r}}=$ Power due to Rolling Resistance

$\mathrm{P}_{\mathrm{i}}=$ Power due to Inertial Force

Power due to Aerodynamic Drag: It is the power required to overcome the Aerodynamic drag (Vehicle traveling at a speed in air encounters a force resisting its motion. This force is referred to as aerodynamic drag). 
www.rspsciencehub.com

$F_{d}=1 / 2 \rho C_{d} A v^{2}$ (Drag Force)

$P_{d}=1 / 2 \rho C_{d} A v^{3}$

$\mathrm{F}_{\mathrm{d}}=0.5 * \rho * \mathrm{C}_{\mathrm{d}} * \mathrm{~A} * \mathrm{v}^{2}$

$\mathrm{F}_{\mathrm{d}}=0.5 * 1.225 * 0.9 * 0.4293 * 16.67 * 16.67$

$\mathrm{F}_{\mathrm{d}}=65.76 \mathrm{~N}$

$\mathrm{P}_{\mathrm{d}}=\mathrm{F}_{\mathrm{d}} * \mathrm{v}$

$\mathrm{Pd}=1096.21 \mathrm{~W}$

$\rho=$ Air Density $\left(\mathrm{Kg} / \mathrm{m}^{3}\right)$

$\mathrm{C}_{\mathrm{d}}=$ Coefficient of Drag

$\mathrm{A}=$ Front air contact area $\left(\mathrm{m}^{2}\right)$

$\mathrm{v}=$ Vehicle Velocity $\left(\mathrm{m} / \mathrm{s}^{2}\right)$

Power due to Rolling Resistance: The power required to overcome the Rolling resistance (Rolling resistance, also called rolling friction or rolling drag, is the force resisting the motion when a body (such as a tire, or wheel) rolls on a surface).

$\mathrm{F}_{\mathrm{r}}=\mathrm{mg} \mu \operatorname{Cos} \theta$ (Rolling Resistance)

$\mathrm{P}_{\mathrm{r}}=\mathrm{mg} \mu \mathrm{v} \operatorname{Cos} \theta$

$\mathrm{F}_{\mathrm{r}}=\mathrm{m} * \mathrm{~g} * \mu^{*} \operatorname{Cos}(\theta)$

$\mathrm{F}_{\mathrm{r}}=195 * 9.81 * 0.013 * \operatorname{Cos}(0)$

$\mathrm{F}_{\mathrm{r}}=24.86 \mathrm{~N}$

$\mathrm{P}_{\mathrm{r}}=\mathrm{F}_{\mathrm{r}}^{*} \mathrm{~V}$

$\mathrm{P}_{\mathrm{r}}=414.41 \mathrm{~W}$

$\mathrm{g}=$ Acceleration due to gravity $\left(\mathrm{m} / \mathrm{s}^{2}\right)$

$\mu=$ Coefficient of friction

$\theta=$ Gradient angle or slope angle (degree)

$\mathrm{v}=$ Velocity of vehicle $\left(\mathrm{m} / \mathrm{s}^{2}\right)$

Power due to Inertial Force: Power required overcoming the force of Inertia. (It is the resistance of a physical object to any change in its velocity).

$$
\mathrm{F}_{\mathrm{i}}=\mathrm{ma} \text { (Inertial Force) }
$$

$\mathrm{P}_{\mathrm{i}}=\mathrm{mav}$

$\mathrm{F}_{\mathrm{i}}=\mathrm{m} * \mathrm{a}$

$\mathrm{F}_{\mathrm{i}}=195 * 0.8$

$\mathrm{F}_{\mathrm{i}}=156 \mathrm{~N}$

$\mathrm{P}_{\mathrm{i}}=\mathrm{F}_{\mathrm{i}} *_{\mathrm{V}}$

$\mathrm{P}_{\mathrm{i}}=2600.52 \mathrm{~W}$

$\mathrm{m}=$ Vehicle Mass with driver $(\mathrm{kg})$

$\mathrm{a}=$ Vehicle Acceleration $\left(\mathrm{m} / \mathrm{s}^{2}\right)$

$\mathrm{v}=$ Velocity of vehicle $\left(\mathrm{m} / \mathrm{s}^{2}\right)$

Thus,

Total Power $\left(\mathrm{P}_{\mathrm{t}}\right)$

$\mathrm{P}_{\mathrm{t}}=\mathrm{P}_{\mathrm{d}}+\mathrm{P}_{\mathrm{r}}+\mathrm{P}_{\mathrm{i}}$

$\mathrm{P}_{\mathrm{t}}=4111.14 \mathrm{~W}$

$\mathrm{F}_{\mathrm{t}}=\mathrm{F}_{\mathrm{d}}+\mathrm{F}_{\mathrm{r}}+\mathrm{F}_{\mathrm{i}}$

$\mathrm{F}_{\mathrm{t}}=246.62 \mathrm{~N}$

Thus, the selected battery pack must be such that it fulfils these requirements.

\section{Battery Selection}

The Battery selection is based on the requirements calculated theoretically and practically. Thus, Liion [2] battery comes into consideration because of their various advantages over other types of batteries. The most economical lithium-ion battery w.r.t of cost-to-energy ratio is the cylindrical 18650 (size is $18 \mathrm{~mm} \times 65.2 \mathrm{~mm}$ ). Most 18650 batteries last between 300 and 500 charge cycles, but battery lifetime can be extended far beyond those numbers if charged regularly before complete discharge. A $3.7 \mathrm{v}$ a $3400 \mathrm{mAh} 18650$ can store about $2 \mathrm{Ah}$ to $\max$ of $3.5 \mathrm{Ah}$. It can store about 10-to-13-watt hours of Energy.

\section{Specifications of battery:}

Type of Battery: INR 18650 [2]

\begin{tabular}{|l|l|}
\hline ITEM & SPECIFICATIONS \\
\hline Capacity & $\begin{array}{l}\text { Nom. }=2600 \mathrm{mAh} \\
\text { Min. }=2550 \mathrm{mAh}\end{array}$ \\
\hline Nominal voltage & Average 3.7 V \\
\hline $\begin{array}{l}\text { Standard charge: } \\
\text { Constant Current and } \\
\begin{array}{l}\text { Constant Voltage } \\
\text { (CC/CV) }\end{array}\end{array}$ & $\begin{array}{l}\text { Current }=1150 \mathrm{mAh} \\
\text { Voltage }=4.2 \mathrm{~V} \\
\text { End Current }=50 \mathrm{~mA}\end{array}$ \\
\hline Max. Charge Current & 2600Ah \\
\hline $\begin{array}{l}\text { Standard Discharge: } \\
\text { Constant Current (CC) }\end{array}$ & $\begin{array}{l}\text { Current }=460 \mathrm{~mA} \\
\text { End Voltage }=3.0 \mathrm{~V}\end{array}$ \\
\hline $\begin{array}{l}\text { Max. Discharge } \\
\text { Current }\end{array}$ & $\begin{array}{l}5200 \mathrm{mAh} \text { (for } \\
\text { continuous discharge) }\end{array}$ \\
\hline Weight & Approx. 46.5 g \\
\hline Operating Temperature & $\begin{array}{l}\text { Charge: 0 to 45 C } \\
\text { Discharge: }-20 \text { to 60 C }\end{array}$ \\
\hline C rate & $1 \mathrm{C}$ \\
\hline Diameter & $18.3 \pm 0.1 \mathrm{~mm}$ \\
\hline Height & $64.9 \pm 0.2 \mathrm{~mm}$ \\
\hline Cycle Life & 600 Cycle \\
\hline Efficiency & $98 \%$ \\
\hline
\end{tabular}

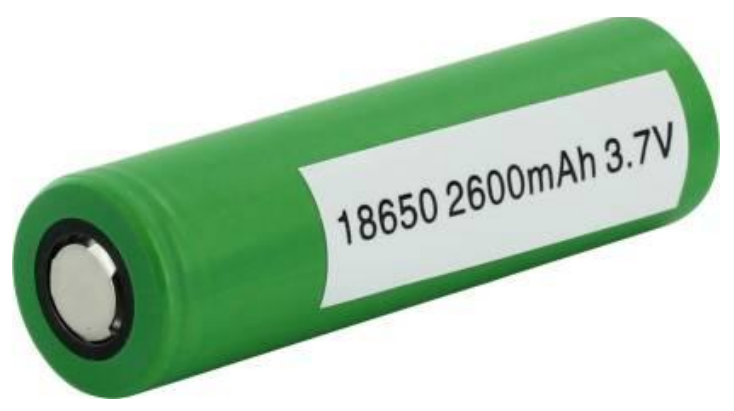

Fig.2 Figure of 18650 Battery Cell.

\section{Battery Pack Calculations}

After selecting the battery development of the battery pack is the next process. Key things to be considered while developing a battery pack is the 
"Power" in Wh and the Series-Parallel combination of cells(batteries) to be arranged. Thus, making a battery pack effective for use.

Power $=2000 \mathrm{Wh}$

Voltage $=48 \mathrm{~V}$

Current $=2000 / 48=41.67 \mathrm{Amp}$

Number of Cells in Parallel $=41.67 / 2.6=16$

Number of Cells in Series $=48 / 3.7=13$

Series/Parallel Combination $=13 \mathrm{~S} 16 \mathrm{P}$

Battery Pack Capacity $=41.67 \mathrm{Ah}$

Power Capacity $=2000 \mathrm{Wh}$

For the use in our Electric Kart, we used two battery pack in parallel, as using two battery packs in parallel fulfills our Power, Current and Voltage requirement along with overcoming the losses incurred by a single battery pack, like decreasing thetotal resistance.

Weight reduction along with size reduction of the battery pack can be achieved by this configuration.

Therefore,

Power $=4000 \mathrm{Wh}$

Voltage $=48 \mathrm{~V}$

Current $=82.5 \mathrm{Amp}$

Capacity $=82.5 \mathrm{Ah}$

Battery Life $=$ Capacity $/$ Load current

Battery Life $=82.5 / 67=1.23 \mathrm{hrs}$ (ideal)

Battery Life $=73.8$ mins

$80 \%$ used in allowances:

$1.23 * 0.8=0.984 \mathrm{hrs} .=59.04 \mathrm{mins}$

\subsection{Charging Time:}

Charging time is one of the principal challenges of secondary batteries. This parameter indicates how much time it takes for a fully discharged cell to be fully charged.

$\mathrm{T}=\mathrm{Ah}$ (Battery)/A

Charging current should $25 \%$ of Ah rating of battery

Charging Current $=82.5 * 0.25=20.625 \mathrm{Amp}$

$\mathrm{T}=82.5 / 20.625=4$ hours (Ideal condition no losses)

In realistic conditions there are $40 \%$ losses

$82.5 * 0.4=33 \mathrm{Amp}$

$\mathrm{T}=82.5+33 / 20.625=5.6$ hours

\subsection{Range for the Battery:}

It is the driving range of a vehicle using only power from its electric battery pack to cross a given driving cycle. Also, it means the total range per charge. Range of a battery pack is very essential in an Electric vehicle because of the fact that moving from a Combustion Engine vehicle towards an Electric vehicle must be economic along with better range (in $\mathrm{km}$ ) per unit fuel.

Voltage $=48 \mathrm{~V}$

Current $=35.8 \mathrm{amp}$

$\mathrm{P}_{\mathrm{m}}=1435 \mathrm{~W}$

$\mathrm{RPM}_{\mathrm{m}}=2551$

$\mathrm{RPM}_{\mathrm{w}}=1122.44$

$\mathrm{W}=117.54 \mathrm{rad} / \mathrm{sec}$

$\mathrm{v}=59.24 \mathrm{~km} / \mathrm{h}=16.45 \mathrm{~m} / \mathrm{s}$

$\rho=1.225 \mathrm{~kg} / \mathrm{m}^{3}$

$\mathrm{C}_{\mathrm{d}}=0.9$

$\mu=0.013$

$\mathrm{A}=0.4293 \mathrm{~m}^{2}$

$\mathrm{m}=195 \mathrm{~kg}$

$\mathrm{g}=9.81 \mathrm{~m} / \mathrm{s}^{2} \tau_{\mathrm{m}}=4.19 \mathrm{Nm}$

$\tau_{\mathrm{w}}=9.33 \mathrm{Nm}$

Drag:

$\mathrm{F}_{\mathrm{d}}=0.5 * \rho * \mathrm{C}_{\mathrm{d}} * \mathrm{~A} * \mathrm{v}^{2} \mathrm{~F}_{\mathrm{d}}=64.03 \mathrm{~N}$

$\mathrm{P}_{\mathrm{d}}=\mathrm{F}_{\mathrm{d}} * \mathrm{v}$

$\mathrm{P}_{\mathrm{d}}=1053.29 \mathrm{~W}$

Rolling Resistance: $\quad \mathrm{F}_{\mathrm{r}}=\mathrm{m}^{*} \mathrm{~g} * \mu$

$\mathrm{F}_{\mathrm{r}}=24.86 \mathrm{~N}$

$\mathrm{P}_{\mathrm{r}}=\mathrm{F}_{\mathrm{r}} * \mathrm{~V}$

$\mathrm{P}_{\mathrm{r}}=408.94 \mathrm{~W}$

Total Power:

$\mathrm{P}_{\mathrm{t}}=\mathrm{P}_{\mathrm{d}}+\mathrm{P}_{\mathrm{r}}+\mathrm{P}_{\mathrm{m}}$

$\mathrm{P}_{\mathrm{t}}=2897.23 \mathrm{~W}$

Current Requirement: $\quad \mathrm{I}=\mathrm{P}_{\mathrm{t}} / \mathrm{V}$

$\mathrm{I}=2897.23 / 48$

$\mathrm{I}=60.35 \mathrm{Amp}$

$\mathrm{Wh} / \mathrm{km}=2897.23 \mathrm{~W} / 59.24 \mathrm{~km} / \mathrm{h}$

$\mathrm{Wh} / \mathrm{km}=48.91 \mathrm{Wh} / \mathrm{km}$

Range $=($ Capacity $(\mathrm{Wh})) /(\mathrm{Wh} / \mathrm{km})$

Range $=3960 / 48.91=80.96 \mathrm{~km}$

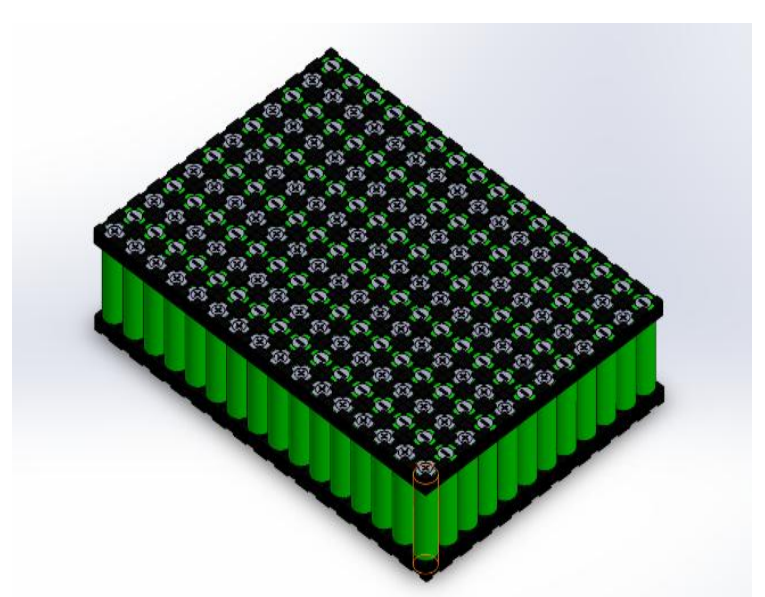

Fig. 3 Diagram of 13S 16P Battery Pack 


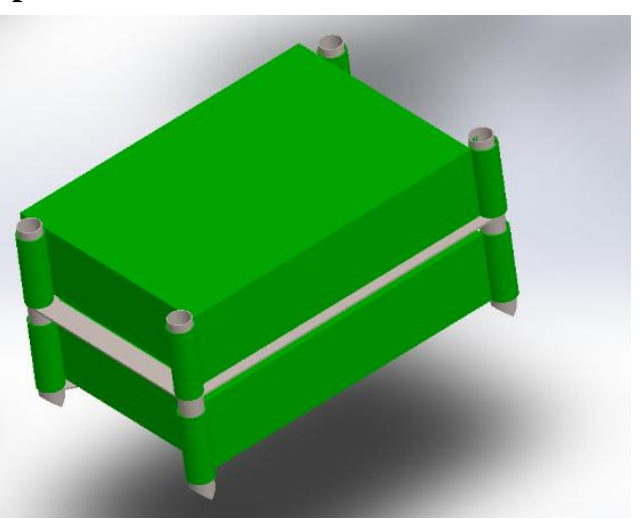

Fig.4 Diagram for Parallel Configuration of Battery Pack

6. Thermal Analysis and CFD

In broad terms, if something gets too hot or too cold, it will not function the way it was designed to function. Thermal analysis helps drive the design so that the product doesn't reach those temperatures.In Li-ion battery cells the temperature affects the electrochemical reactions, charge acceptance, power and energy capability, life cycle, reliability, round trip efficiency, and cost. Moreover, in electric vehicles, battery temperature increases during discharge along with a summit for high current rates. In general, excessive temperature degrades the performance and restricted thermal dissipation can even cause burning in Li-ion battery cells. Great importance is also given to the safety of battery regarding heat accumulation caused by the flammability and explosiveness of lithium.

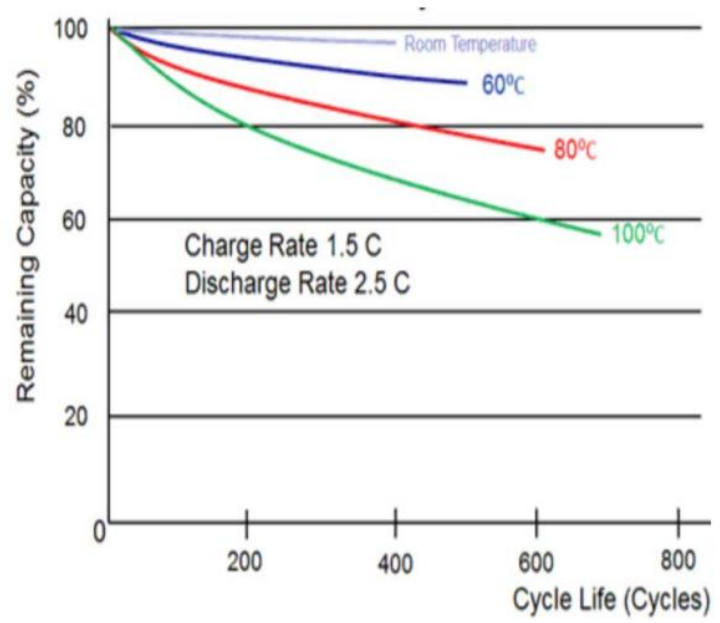

Fig.5 Effect of Temperature on battery [3]

The temperature upraises two very important matter in Li-ion batteries: safety risks and material aging. The material aging is related to the operative cycles and to the attained temperature levels in the course of working conditions. The safety risks lead to high temperature values during discharge over the permitted level. Furthermore, in Li-ion battery pack the temperature distribution also has huge importance. The non-uniformity in temperature of cell pack favors localized decline in single battery elements, this institute efficiency losses (as ohmic resistance) and lifespan reduction in the complete pack.

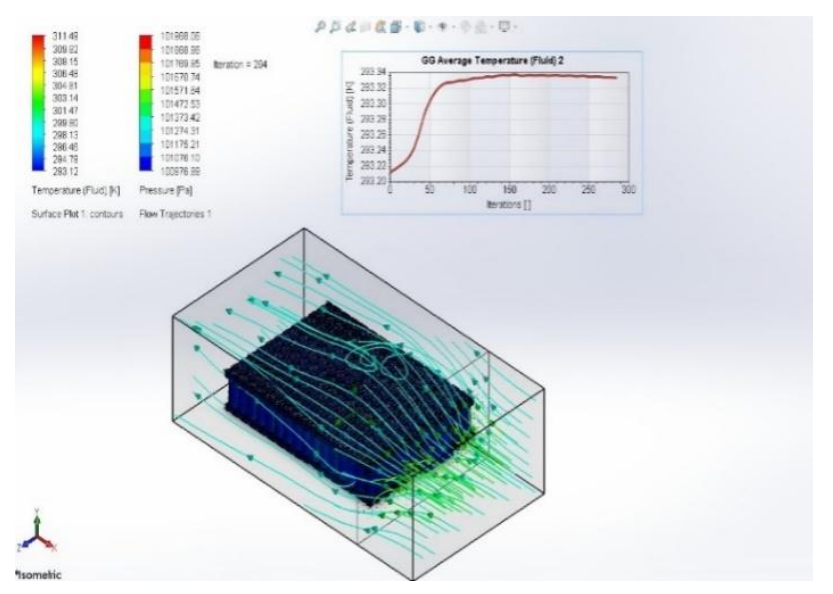

Fig.6 CFD of Battery Pack

Fig.6 shows the temperature variation in battery pack while running, along with the pressure difference i.e., the amount of pressure applied by the fluid (air in this case) on the battery pack while the vehicle is moving at a speed of $20 \mathrm{~m} / \mathrm{sec}$. The graph in Fig.6 shows the fluid Temperature variation in contact with the battery pack.

Table 1 CFD results

\begin{tabular}{|c|c|c|}
\hline Name & Maximum & Minimum \\
\hline Pressure [Pa] & 101968.06 & 100976.99 \\
\hline Temperature [K] & 311.49 & 293.12 \\
\hline $\begin{array}{c}\text { Density (Fluid) } \\
{\left[\mathrm{kg} / \mathrm{m}^{\wedge} \text { 3] }\right.}\end{array}$ & 1.21 & 1.14 \\
\hline $\begin{array}{c}\text { Temperature } \\
\text { (Fluid) [K] }\end{array}$ & 311.49 & 293.12 \\
\hline $\begin{array}{c}\text { Heat Transfer } \\
\text { Coefficient } \\
{\left[\mathrm{W} / \mathrm{m}^{\wedge} 2 / \mathrm{K}\right]}\end{array}$ & 384.790 & 0.932 \\
\hline Velocity [m/s] & 23.838 & 0 \\
\hline $\begin{array}{c}\text { Surface Heat Flux } \\
{\left[\mathrm{W} / \mathrm{m}^{\wedge} 2\right]}\end{array}$ & 17.038 & 17.038 \\
\hline Shear Stress [Pa] & 58.92 & 0 \\
\hline $\begin{array}{c}\text { Surface Heat Flux } \\
\text { (Convective) } \\
{\left[\mathrm{W} / \mathrm{m}^{\wedge} \text { 2] }\right.}\end{array}$ & 17.038 & 17.038 \\
\hline
\end{tabular}

Table.1 displays the results of CFD analysis of the Battery pack with an initial fluid velocity of 20 $\mathrm{m} / \mathrm{sec}$ in negative ' $\mathrm{x}$ ' direction. The resultant 
temperature variation shows that the developed Battery pack will be within the expected range, for best performance and near to the ideal output. The high value of heat transfer coefficient indicates that the heat id dissipated effectively from the Battery pack into the environment. Also, the heat flux is used for determining the heat generation inside the battery pack. The Surface heat flux value indicates that the transfer or exchange of heat from the surface of battery pack to the atmosphere is being efficiently done.Hence, results in the table deduce that the battery pack is safe and efficient in use.

\section{Conclusions}

4000W (2000w of individual battery pack) in parallel configuration. The developed battery pack is applicable in an Electric Kart which is efficient along with acceptable range in $\mathrm{Km}$ alongside minimum charging time. Thus, deducing following conclusions:

-The developed battery pack is feasible to be used in an Electric Vehicle with compact design and structural safety, without compromising with the performance.

-The developed Battery pack is cost effective for the output Power range, with the system being easy and feasible to design.

-Various tests performed on the developed Battery Pack indicate that it is safe with respect to Thermal constraints and heat generation. The battery pack is developed in such a way that the heat transfer is performed in an effective manner.

A future scope of work could be to increase the power range of the Battery pack to be applicable in bigger and heavy vehicles as well and to implement various cooling techniques to increase the cooling efficiency of the battery pack.

\section{References}

[1].https://www.energy.gov/eere/vehicles/fact607-january-25-2010-energy-and-powerbattery-type.

[2].https://commonsensehome.com/18650battery/\#: :text=A\%2018650\%20protected $\% 2$ 0battery\%20is,is\%20externally\%20monitored $\% 20$ and $\% 20$ controlled.

[3].NREL, "Battery Pack Thermal Design, NREL (National Renewable Energy Laboratory)," National Renewable Energy Laboratory.

[4]."psychologytpday," $01 \quad 2018 . \quad$ [Online]. Available:

https://www.psychologytoday.com/us/blog/hot -thought/201801/why-is-lithium-good-bothbatteries-and-bipolar-disorder.

[5].Sarrafan, Kaveh; Sutanto, Danny; Muttaqi, Kashem M.; and Town, Graham, "Accurate range estimation for an electric vehicle including changing environmental conditions and traction system efficiency" (2017).

[6].Martin Murnane; Adel Ghazel "A Closer Look at State of Charge (SOC) and State of Health (SOH). Estimation Techniques for Batteries" (2017).

[7].Abdullah Barun Khan, Shadab Faisal, Sankalp Arora; "Selection of Major Components of Tractive System and Accumulator for a Formula Student Vehicle" (2020)

[8].Kukkonen, S. 2014. "Current Trends in Battery Technology," presented at Electric Commercial Vehicles National Seminar, September 24.

[9].2021 ISNEE GKDC CONCEPT Rules.

[10].Dr. Marco EvangelosBiancolini "The evaluation of aerodynamic drag of go-karts by means of coast down test and CFD analysis" (2007).

[11].https://x-engineer.org/automotiveengineering/vehicle/electric-vehicles/evdesign-battery-calculation/

[12].Cicconi P.1, Germani M., Landi D; "Modeling and thermal simulation of a PHEV battery module with cylindrical LFP cellModeling and thermal simulation of a PHEV batterymodule with cylindrical LFP cells" (2013).

[13].AA. Pesaran, Battery thermal models forhybrid vehicle simulations, Journal ofPower Sources, 110(2), 377-82, 2002.

[14].https://www.engineering.com/story/the-manytypes-of-ev-motors

[15].Introduction to Battery Management SystemsFebruary 08, 2021 by Enrico Sanino. 